\title{
Hydroalcoholic Extract and Ethyl Acetate Fraction of Bixa orellana Leaves Decrease the Inflammatory Response to Mycobacterium abscessus Subsp. massiliense
}

\author{
José Lima Viana, ${ }^{1}$ Adrielle Zagmignan, ${ }^{1}$ Luís Felipe Lima Lobato, ${ }^{1}$ \\ Afonso Gomes Abreu Jr., ${ }^{1}$ Luís Cláudio Nascimento da Silva $\mathbb{D}^{1},{ }^{1}$ Joicy Cortez de Sá, ${ }^{1}$ \\ Cristina de Andrade Monteiro, ${ }^{2}$ João Henrique Ghilardi Lago $\left(\mathbb{D},{ }^{3}\right.$ \\ Letícia Machado Gonçalves $\left(\mathbb{D},{ }^{4}\right.$ Rafael Cardoso Carvalho ${ }^{1}{ }^{5}$ \\ Lídio Gonçalves Lima Neto $\mathbb{D}^{1},{ }^{1}$ and Eduardo Martins de Sousa $\mathbb{D i}^{1}$ \\ ${ }^{1}$ Pós-Graduação em Biologia Parasitária, Laboratório de Imunologia e Microbiologia das Infecções Respiratórias, \\ Universidade Ceuma, São Luís, Brazil \\ ${ }^{2}$ Pós-Graduação em Biologia Parasitária, Laboratório de Micologia Médica, Programa de Mestrado em Biologia Parasitária, \\ Universidade Ceuma, São Luís, Brazil \\ ${ }^{3}$ Centro de Ciências Naturais e Humanas, Universidade Federal do ABC, São Paulo, Brazil \\ ${ }^{4}$ Pós-graduação em Odontologia, Laboratório de Odontologia, Universidade Ceuma, São Luís, Brazil \\ ${ }^{5}$ Programa de Pós-Graduação em Ciências da Saúde, Universidade Federal do Maranhão, São Luís, Brazil \\ Correspondence should be addressed to Eduardo Martins de Sousa; edmsousa@hotmail.com
}

Received 25 March 2018; Accepted 18 August 2018; Published 2 October 2018

Academic Editor: Antonio Vassallo

Copyright (c) 2018 José Lima Viana et al. This is an open access article distributed under the Creative Commons Attribution License, which permits unrestricted use, distribution, and reproduction in any medium, provided the original work is properly cited.

\begin{abstract}
The incidence of infections caused by rapidly growing mycobacteria (RGM), especially Mycobacterium abscessus subsp. massiliense $(\mathrm{Mabs})$, is increasing worldwide. Severe infections are associated with abscess formation and strong inflammatory response. This study evaluated the antimicrobial and anti-inflammatory activities of a hydroalcoholic extract (BoHE) and ethyl acetate fraction (BoEA) of Bixa orellana leaves. Antimicrobial activity was evaluated by broth microdilution to determine the minimum inhibitory (MIC) and the minimum bactericidal (MBC) concentrations. Cytotoxicity was evaluated using erythrocytes and RAW 264.7 cells. Nitric oxide (NO) was assayed in stimulated RAW 264.7 cells, and inflammatory cell migration and acute toxicity were evaluated in a Mabs-induced peritonitis mouse model. The compounds present in BoEA were identified by high performance liquid chromatography and mass spectrometry (HPLC-MS). The MIC and MBC values were $2.34 \mathrm{mg} / \mathrm{mL}$ and $37.5 \mathrm{mg} / \mathrm{mL}$ for BoHE and $0.39 \mathrm{mg} / \mathrm{mL}$ and $6.25 \mathrm{mg} / \mathrm{mL}$ for BoEA. The extracts did not induce significant toxicity in erythrocytes and RAW 264.7 cells. High levels of NO induced by Mabs were decreased by treatment with both extracts. The anti-inflammatory activity was confirmed in vivo by significant reduction of the cell migration to the peritoneum following BoHE and BoEA pretreatment. Animals treated with BoHE or BoEA did not show signs of acute toxicity in stomach, liver, and kidney. The chemical characterization of BoEA (the most active extract) revealed that kaempferol-3-O-coumaroyl glucose is its major component. The extract of $B$. orellana may be effective for treating infections caused by Mabs.
\end{abstract}

\section{Introduction}

The Mycobacterium abscessus complex is formed by $M$. abscessus subsp. abscessus, M. abscessus subsp. massiliense, and M. abscessus subsp. bolletii $[1,2]$. These rapidly growing mycobacteria (RGM) cause hospital outbreaks of lung infections in patients with cystic fibrosis, chronic lung disease (bronchiectasis, nodules, and cavitations), postsurgical infections [3, 4], skin and soft tissue infections in immunocompromised patients $[5,6]$, and peritonitis in peritoneal dialysis patients [7]. 
An impermeable cell wall composed of peptidoglycans and mycolic acids makes $M$. abscessus subsp. massiliense and other RGM species naturally resistant to antimicrobials and disinfectants $[8,9]$ and creates challenges in the search for new treatments [10]. Acquired macrolide resistance may develop during treatment of $M$. abscessus subsp. massiliense lung infections and is conferred by mutations in the drug binding pocket of the 23S rRNA gene $(r r l)$ at nucleotide positions 2058 and 2059 [11-13].

Previous studies have described Bixa orellana (also known as urucum) as a source of antimicrobial agents. The seeds of this plant are currently used in folk medicine to treat heart disease, gastrointestinal problems, respiratory infections, burns [14], diabetes, skin infections, fever, measles, gonorrhea, diarrhea, and asthma [15]. The antimicrobial action [16] and antioxidant activity [17] of the methanolic extract of $B$. orellana seeds and leaves against Gram-positive bacteria (e.g., S. mutans and S. sanguinis) have previously been described. In addition, the antimalarial activity of essential oils and root extracts [18] and the anti-inflammatory effects of aqueous extracts of the leaves $[19,20]$ have been also reported.

This study evaluated the antimicrobial and antiinflammatory activities of BoHE and BoEA leaf extracts of $B$. orellana, which is a plant widely used in Brazilian folk medicine to treat Mycobacterium infections and other inflammatory disorders [14]. The antimicrobial activity was tested against M. abscessus subsp. massiliense (Mabs), an emerging human pathogen implicated in hospital outbreaks with natural resistance to several last generation antimicrobials. The cytotoxic effects of BoHE and BoEA were assayed using human erythrocytes and murine RAW 264.7 cells. The acute toxicity and the in vivo anti-inflammatory activities of the extracts were evaluated in a murine peritonitis model induced by inactivated Mabs.

\section{Materials and Methods}

2.1. Collection of B. orellana Leaves and Preparation of Extract and Fractions. Fresh B. orellana leaves were collected (June-July 2016) and identified at the Ático Seabra Herbarium of Federal University of Maranhão (São Luís, Brazil; voucher specimen 1147). The cleaned leaves were oven dried at $40^{\circ} \mathrm{C}$ for 3 days, ground in a mill, and extracted for 24 $\mathrm{h}$ in $70 \%$ ethanol by maceration with agitation. The sample was filtered, and the resulting filtrate was concentrated in a rotary evaporator under low pressure at $50^{\circ} \mathrm{C}$. The concentrate was lyophilized (named $\mathrm{BoHE}$ ) and stored at $-20^{\circ} \mathrm{C}$ until use. BoHE was submitted to liquid-liquid fractionation using hexane, chloroform, and ethyl acetate with a series of increasing polarity to produce hexane (BoHex), chloroform (BoCl), and ethyl acetate (BoEA) fractions. BoHE and BoEA were resuspended in a saline solution $(0.9 \% \mathrm{NaCl})$.

2.2. Determination of Total Phenol and Total Flavonoid Contents. The content of total phenols was estimated using the Folin-Ciocalteau method for total phenols (Singleton et al., 1965), with some modifications. Samples of $20 \mu \mathrm{L}$ of each extract $(1 \mathrm{mg} / \mathrm{mL})$ and $100 \mu \mathrm{L}$ of the Folin-Ciocalteu reagent were mixed; and after 3 minutes of incubation at room temperature, $80 \mu \mathrm{L}$ of a solution of sodium bicarbonate $(0.7$ M) was added. The reaction was kept in the dark for $2 \mathrm{~h}$ at room temperature and the absorbance was measured at 735 nm using a microplate reader (BioTek UQuant MQX200). PBS (vehicle) was used as negative controls. Gallic acid was used as standard, and the results were calculated based on the calibration curve of gallic acid (10-100 mg/L) and expressed as mg equivalent of gallic acid per gram of extract (GAE /g extract).

The flavonoid content was determined according to the colorimetric method of aluminum chloride (Woisky and Salatino, 1998). The extracts were tested at the concentration of $1 \mathrm{mg} / \mathrm{mL}$, and the quercetin was used as standard compound $(10-100 \mathrm{mg} / \mathrm{L})$. The sample $(100 \mu \mathrm{L})$ was mixed with $100 \mu \mathrm{L}$ of the reagent [2\% aluminum chloride $\left(\mathrm{AlCl}_{3}\right)$ in methanol]. After $1 \mathrm{~h}$ on incubation in the dark at room temperature, the absorbance was read at $420 \mathrm{~nm}$. PBS was used as negative control. The results were expressed as $\mathrm{mg}$ equivalent of quercetin per gram of extract (mg QE/g).

2.3. RGM Strain. An isolate of $M$. abscessus massiliense (Go01) obtained from patients with hospital outbreaks of postoperative infections [21] was used in the study. The sample was generously provided by the Laboratory of Immunopathology of Respiratory Infections from the Institute of Tropical Pathology and Public Health, the Federal University of Goiás. The use of the clinical isolate was authorized by freely given written informed consent using a form approved by the institutional ethics committee $\left(\mathrm{N}^{\circ}\right.$ : 21357413.4.0000.5084).

2.4. Antimicrobial Susceptibility. Minimum inhibitory (MIC) and minimal bactericidal (MBC) concentrations were determined as described in the ATS/IDSA guidelines [5]. In brief, the extracts were diluted (from $200 \mathrm{mg} / \mathrm{mL}$ to $0.04 \mathrm{mg} / \mathrm{mL}$ ) in microplates and microbial suspensions (at $2 \times 10^{3} \mathrm{CFU} / \mathrm{mL}$ ) were added. After $72 \mathrm{~h}$ of incubation at $37^{\circ} \mathrm{C}$, a resazurin suspension $(0.01 \% \mathrm{w} / \mathrm{v})$ was added followed by a further incubation ( $16 \mathrm{~h}$ incubation at $37^{\circ} \mathrm{C}$ ). A pink color indicated the presence of living bacteria and a purple color indicated dead bacteria. Amikacin was used as a control. The extract concentrations without visible growth were inoculated on $\mathrm{MH}$ agar plates. The MBC was determined after 5-7 days incubation at $37^{\circ} \mathrm{C}$. The $\mathrm{MBC}$ was the lowest extract concentration that prevented $99.9 \%$ bacterial growth expressed in $\mathrm{CFU} / \mathrm{mL}[22,23]$.

\subsection{Cytotoxicity Assays}

2.5.1. Hemolytic Activity. Heparinized blood was obtained from three healthy volunteers (types A, B or O serotypes) that were nonsmokers and had not taken any medication for at least 15 days. They were 18-35 years of age and had given written informed consent. The protocol $\left(\mathrm{N}^{\circ} 1.570 .437\right)$ was approved by the Research Ethics Committee of Ceuma University. Erythrocytes were obtained by centrifugation at $1500 \mathrm{rpm}$ for $10 \mathrm{~min}$ immediately after collection, removal of the plasma, and washing three times in $\mathrm{pH} 7.4$ phosphate 
buffered saline. After washing, a $1 \%$ erythrocytes suspension was prepared in PBS. Samples $(0.4 \mathrm{~mL})$ of BoHE $(0.58$ $\mathrm{mg} / \mathrm{mL}$ to $9.36 \mathrm{mg} / \mathrm{mL})$ or BoEA $(0.09 \mathrm{mg} / \mathrm{mL}$ to 1.56 $\mathrm{mg} / \mathrm{mL}$ ) were added to $1.1 \mathrm{~mL}$ erythrocyte suspension. PBS and $0.05 \%$ Triton X-100 solution were used as negative and positive controls, respectively. After $60 \mathrm{~min}$ incubation at room temperature, the cell suspensions were centrifuged, and the concentration of hemoglobin in the supernatant was measured at $540 \mathrm{~nm}$ [24]. The result was reported as the mean of three independent assays. Hemolytic activity was expressed in relation to Triton X-100 and calculated using the following formula:

$\%$ hemolysis $=[(A s-A b) \times 100] /(A c-A b)$, where $\mathrm{Ab}$ is absorbance of control (blank without extract), As is absorbance in the presence of the extract, and Ac is absorbance in the presence of Triton X-100.

2.5.2. Cytotoxicity towards Murine RAW 264.7 Cells. Murine RAW 264.7 cells were maintained in Dulbecco's high glucose modified Eagle's medium (DMEM) supplemented with $10 \%$ fetal bovine serum (Sigma-Aldrich), streptomycin 100 $\mu \mathrm{g} / \mathrm{mL}$, and penicillin $100 \mathrm{UI} / \mathrm{mL}$. After growth was established, cells were plated in 96-well plates at $2 \times 10^{5}$ cells/well and treated with BoHE $(1.17 \mathrm{mg} / \mathrm{mL}$ to $9.36 \mathrm{mg} / \mathrm{mL})$ or BoEA $(0.19 \mathrm{mg} / \mathrm{mL}$ to $1.56 \mathrm{mg} / \mathrm{mL})$. DMEM and $0.05 \%$ Triton $\mathrm{X}$ were positive and negative controls, respectively. The plated were incubated at $37^{\circ} \mathrm{C}$ and $5 \% \mathrm{CO}_{2}$. After $24 \mathrm{~h}$, the medium of each well was removed and DMEN medium containing $5 \mathrm{mg} / \mathrm{mL}$ MTT (3-(4,5-dimethylthiazol-2-yl)-2,5diphenyltetrazolium bromide; Sigma-Aldrich) was added to each well. The plates were incubated for $4 \mathrm{~h}$ at $37^{\circ} \mathrm{C}$ and $5 \%$ $\mathrm{CO}_{2}$ in the dark. The supernatants were discarded, and the formazan crystals were dissolved in $100 \mu \mathrm{L}$ dimethyl sulfoxide (DMSO). Absorbance was read at $540 \mathrm{~nm}$ using a microplate reader (Thermo Plate), and the results were expressed as a percentage of the maximal value of the positive control and reported as means of three independent assays \pm the standard deviation $[25,26]$.

2.6. In Vitro Anti-inflammatory Assay. The effects of BoHE and BoEA on nitric oxide (NO) production by murine RAW 264.7 cells induced by Mabs were evaluated using Griessbased assay. For this, RAW 264.7 cells were plated at a density of $2 \times 10^{5}$ cells/well in 96-well plates and infected with Mabs at $1 \times 10^{8} \mathrm{CFU} / \mathrm{mL}$. After $1.5 \mathrm{~h}$, the cells were exposed to BoHE $(1.17 \mathrm{mg} / \mathrm{mL}$ and $9.36 \mathrm{mg} / \mathrm{mL})$ or BoEA $(0.19 \mathrm{mg} / \mathrm{mL}$ to $1.56 \mathrm{mg} / \mathrm{mL})$. Mabs-infected cells without any extract treatment were considered as positive control. Cells treated and incubated with $1 \mu \mathrm{g} / \mathrm{mL}$ LPS (E. coli 0111 lipopolysaccharide; Sigma-Aldrich, Saint Louis, MO, USA) and $100 \mu \mathrm{g} / \mathrm{mL}$ IFN- $\gamma$ (Interferon-gamma; BD Pharmingen) were also used as positive control. After $24 \mathrm{~h}$ incubation at $37^{\circ} \mathrm{C}$ in $5 \% \mathrm{CO}_{2}$, the supernatants were collected $(50 \mu \mathrm{L})$ and incubated with $50 \mu \mathrm{L}$ Griess reagent (1\% sulfanilamide, $0.1 \%$ naphthyl ethylenediamine, and 2.5\% phosphoric acid) for 10 min at room temperature in the dark, and the absorbance at $540 \mathrm{~nm}$ was compared with that of a standard curve derived from $0-300 \mu \mathrm{M}$ NO [26]. Results were expressed as $\mu \mathrm{M}$.

\subsection{Animal Experimentation}

2.7.1. Animals. Female C57BL/6 mice 6 to 8 weeks of age, weighing from $20 \mathrm{~g}$ to $25 \mathrm{~g}$, were housed in plastic cages at room temperature $\left(23 \pm 1^{\circ} \mathrm{C}\right)$ and a $12 \mathrm{~h}$ light-dark cycle and given balanced laboratory food and water ad libitum. All experimental procedures were conducted following the laboratory animal care standards of the Ceuma University Animal Experimentation and Use Committee (approval $\mathrm{N}^{\circ}$ 107/14) in accordance with the UK Animals (Directive 2010/63/EU).

2.7.2. Clinical Isolates and Preparation of Inocula. Mabs bacterial suspensions were adjusted to $1 \times 10^{8} \mathrm{CFU} / \mathrm{mL}$ in $\mathrm{pH} 7.4$ phosphate buffered saline with vigorous stirring to disperse cell clumps. The bacterial cells were heat killed at $90^{\circ} \mathrm{C}$ for 1 h.

2.7.3. Experimental Design and Induction of Peritonitis by Mabs. Animals were randomly allocated into seven groups ( $n=5-6$ animals) that received a single oral dose of $0.9 \%$ saline solution at $1 \mathrm{~mL} / \mathrm{kg}$ (groups I and II); BoHE at 50 $\mathrm{mg} / \mathrm{kg}$ (group III) or $150 \mathrm{mg} / \mathrm{kg}$ (group IV); BoEA at $50 \mathrm{mg} / \mathrm{kg}$ (group V) or $150 \mathrm{mg} / \mathrm{kg}$ (group VI); and $5 \mathrm{mg} / \mathrm{kg}$ dexamethasone (group VII). After $1 \mathrm{~h}$ of treatment, the animals from groups II to VII received intraperitoneal injections of $0.1 \mathrm{~mL}$ $1 \times 10^{7} \mathrm{CFU}$ heat killed Mabs.

2.7.4. Determination of Cell Migration to Peritoneal Cavity. Peritoneal liquid was obtained $4 \mathrm{~h}$ and $24 \mathrm{~h}$ after induction of peritonitis. For this, each animal received $80 \mathrm{mg} / \mathrm{kg}$ ketamine hydrochloride and $10 \mathrm{mg} / \mathrm{kg}$ xylazine hydrochloride. Lavage was performed with the introduction of $3 \mathrm{~mL}$ of $1 \mathrm{mM}$ EDTA in PBS into the abdominal cavity with a sterile, disposable syringe, and needle. The aspirated contents were transferred to a tube. The leukocytes present in the peritoneal liquid were counted in a Neubauer chamber after a 1:2 v/v dilution in Turk's solution. The differential leukocyte count was performed in a $100 \mu \mathrm{m}$ hanging drop of sample obtained by cytocentrifugation at $600 \mathrm{rpm}$ for $10 \mathrm{~min}$. The slides were Giemsa stained, and the 100 cells were counted by optical microscopy at $1000 \times$ using an oil immersion objective.

2.7.5. Acute Toxicity Assay. Stomach, liver, and kidneys were in fixed $10 \%$ paraformaldehyde, embedded in paraffin, sectioned at $5 \mu \mathrm{m}$, and stained with hematoxylin and eosin (H\&E). The slides were evaluated by optical microscopy (Axio Imager Z2; Carl Zeiss, Oberkochen, Germany), at 40x to $400 \times$ increments, and ten fields per slide were evaluated by an experienced pathologist for the presence or absence, distribution, and severity of histological changes.

2.8. HPLC-DAD-ESI-IT/MS Analysis. The chemical constituents of BoEA were analyzed in a high-performance liquid chromatography (HPLC) using a LC-10AD system (Shimadzu, Japan) equipped with a photodiode array detector (DAD) and coupled to an Esquire 3000 Plus ion-trap mass spectrometer (Bruker Daltonics, Bremen, Germany), using electrospray ionization (ESI) using argon as collision gas and $80 \mathrm{eV}$ as collision energy. Separation was performed using 
Phenomenex Kinetex C-18 column $(250 \times 4.6 \mathrm{~mm}, 5 \mu \mathrm{m}$; Torrance, CA, USA). The column oven was maintained at room temperature. HPLC was set up with an elution gradient as follows: $0-2 \mathrm{~min}, 5 \% \mathrm{~B} ; 2-10 \mathrm{~min}, 5-25 \% \mathrm{~B} ; 10-20 \mathrm{~min}$, 25-40\% B, 20-30 min, 40-50\% B, 30-40 min, 50-60\% B, 40$50 \mathrm{~min}$. Acetic acid (2\%) in Milli-Q water was used as mobile phase $\mathrm{A}$ and methanol was used as mobile phase B.

The injection volume consisted of $25 \mu \mathrm{L}$ of reconstituted sample at $5 \mathrm{mg} / \mathrm{mL}$ and a flow rate of $0.6 \mathrm{~mL} / \mathrm{min}$. Detection was by a diode array detector (DAD) at 200-500 nm and a direct mass spectrometry/mass spectrometry method in negative electrospray (-ESI) mode with the detector voltage maintained at $4.0 \mathrm{kV}$, an ion source of $40 \mathrm{~V}$, and capillary temperature of $320^{\circ} \mathrm{C}$. The nebulizing gas was nitrogen $\left(\mathrm{N}_{2}\right)$ flowing at $7 \mathrm{~mL} / \mathrm{min}$ and sheath gas provided at a pressure of $27 \mathrm{psi}$, and helium was used as the four collision gas. The analyses were performed using full-scan mass spectra and data-dependent MS2 scans from 100 to $2000 \mathrm{~m} / \mathrm{z}$. The compounds were identified on the basis of their molecular ion mass fragmentation. The mass spectra were compared with those previously reported [27].

2.9. Statistical Analysis. Data were presented as means \pm standard variation (SD) or percentages. The normality of distributions was determined by the Shapiro-Wilk test, and the differences between groups were evaluated by analysis of variance (ANOVA) followed by Tukey's multiple comparison test using the Graph Prism 6.0 software. P-values $<0.05$ were considered significant.

\section{Results}

3.1. B. orellana Extracts Have Antimicrobial Activity against M. abscessus massiliense. M. abscessus massiliense (Go01) was susceptible to the B. orellana leaf extracts. The BoHE showed a MIC of $2.34 \mathrm{mg} / \mathrm{mL}$ and the $\mathrm{MBC}$ was $37.5 \mathrm{mg} / \mathrm{mL}$, while MIC found in BoEA was $0.39 \mathrm{mg} / \mathrm{mL}$ and the $\mathrm{MBC}$ was $6.25 \mathrm{mg} / \mathrm{mL}$. For both samples, the MBC/MIC ratios were $>4$, which indicated probable bacteriostatic activities [28]. The best results observed for BoEA may be related to its higher phenolic and flavonoid content. BoEA showed a total phenolic content of $1554.75 \pm 56.14 \mathrm{mg}$ GAE/g and total flavonoid content of $146.55 \pm 2.38 \mathrm{mg} \mathrm{QE} / \mathrm{g}$; these values were higher than those found for BoHE (1025.5 $\pm 66.33 \mathrm{mg} \mathrm{GAE} / \mathrm{g}$; $64.82 \pm 2.05 \mathrm{mg} \mathrm{QE} / \mathrm{g})$.

3.2. Cytotoxic Evaluation of B. orellana Extracts. The cytotoxic effects of BoHE and BoEA towards erythrocyte and RAW 264.7 cells are shown in Figure 1. The extracts did not induce significant erythrocyte toxicity; the results were similar to those observed for erythrocytes treated with PBS (it was not possible to calculate IC50). Regarding the results with RAW 264.7 cells, the IC50 values were $7.44 \mathrm{mg} / \mathrm{mL}$ for BoHE and $7.716 \mathrm{mg} / \mathrm{mL}$ for BoEA. The selective index (SI, i.e., the ratio between IC50/MIC values) was 19.8 for BoEA and 3.2 for BoHE. The higher SI value for BoEA indicated a greater antimicrobial efficiency.
3.3. Effects of B. orellana Extracts on NO Production by RAW 264.7 Macrophages Infected with M. abscessus massiliense. Figure 2 shows the effects of $B$. orellana extracts on NO production by RAW 264.7 macrophages infected by Mabs. As expected, the cells infected by Mabs exhibited high levels of NO in their supernatant, which were similar to the values found for the treatment with LPS. This effect was significantly inhibited by the treatment with all concentrations of BoEA (Figure 2(b)) and the lower concentrations of BoHE (0.19 $\mathrm{mg} / \mathrm{mL}$ and $0.39 \mathrm{mg} / \mathrm{mL}$ ) (Figure $2(\mathrm{a})$ ).

3.4. B. orellana Extracts Inhibit Cell Migration Induced by M. abscessus massiliense. The anti-inflammatory effects of BoHE and BoEA were evaluated in an experimental mouse peritonitis model induced by intraperitoneal injection of heat killed Mabs. As shown in Figure 3, high numbers of leukocytes were detected in the peritoneal fluid of animals inoculated with heat killed Mabs after $4 \mathrm{~h}$ and $24 \mathrm{~h}$. This effect was inhibited in animals treated with BoHE or BoEA. After $4 \mathrm{~h}$ of peritonitis, the best results were observed for animals treated with both doses of BoEA $\left(0.81 \pm 0.38 \times 10^{5}\right.$ cells $/ \mathrm{mL}$ for $50 \mathrm{mg} / \mathrm{kg}$ and $0.89 \pm 0.27 \times 10^{5}$ cells $/ \mathrm{mL}$ for $150 \mathrm{mg} / \mathrm{kg}$ ); these results were similar to those observed in animals treated with dexamethasone $\left(0.6 \pm 0.33 \times 10^{5}\right.$ cells $\left./ \mathrm{mL}\right)$. The maximum BoHE inhibition was found at $50 \mathrm{mg} / \mathrm{kg}\left(1.01 \pm 0.3 \times 10^{5}\right.$ cells $/ \mathrm{mL}$ ), while the dose of $150 \mathrm{mg} / \mathrm{kg}$ induced a weak effect $\left(7.64 \pm 0.58 \times 10^{5}\right.$ cells $/ \mathrm{mL}$ ) (Figure 3(a)).

Similar results were observed after 24 hours of inflammation induction (Figure 3(b)). When BoEA was inoculated at $50 \mathrm{mg} / \mathrm{Kg}$, the greatest reduction on total leukocytes levels were observed $\left(0.62 \pm 0.15 \times 10^{5}\right.$ cells $\left./ \mathrm{mL}\right)$, followed by the pretreatment with $\mathrm{BoHE}$ at $50 \mathrm{mg} / \mathrm{kg}\left(1.04 \pm 0.3 \times 10^{5}\right.$ cells $/ \mathrm{mL})$, BoEA at $150 \mathrm{mg} / \mathrm{kg}\left(1.4 \pm 0.65 \times 10^{5}\right.$ cells $\left./ \mathrm{mL}\right)$, and $\mathrm{BoHE}$ at $150 \mathrm{mg} / \mathrm{kg}$ group $\left(1.98 \pm 0.2 \times 10^{5}\right.$ cells $\left./ \mathrm{mL}\right)$. The inhibition in response to BoEA at $50 \mathrm{mg} / \mathrm{kg}$ was stronger than that in response to dexamethasone $\left(0.71 \pm 0.07 \times 10^{5}\right.$ cells/mL).

Regarding the number of polymorphonuclear cells (PMN) in the peritoneal lavage fluid (Figure 3(c)), after 4 hours the best results were also found for animal pretreated with BoEA $\left(0.29 \pm 0.14 \times 10^{5}\right.$ cells $/ \mathrm{mL}$ for BoEA at $50 \mathrm{mg} / \mathrm{kg}$, and $0.39 \pm 0.13 \times 10^{5}$ cells $/ \mathrm{mL}$ for $150 \mathrm{mg} / \mathrm{kg}$ ); however, BoHE administration also induced strong results $(50 \mathrm{mg} / \mathrm{kg}=0.38 \pm$ $0.063 \times 10^{5}$ cells $/ \mathrm{mL} ; 150 \mathrm{mg} / \mathrm{kg}=4.6 \pm 0.49 \times 10^{5}$ cells $\left./ \mathrm{mL}\right)$. All these values were significantly different when compared with the PMN amount found for untreated animal inoculated with heat killed Mabs $\left(8.2 \pm 1.7 \times 10^{5}\right.$ cells $\left./ \mathrm{mL}\right)$. In addition, the results were similar to those in dexamethasone-treated controls $\left(0.48 \pm 0.2 \times 10^{5}\right.$ cells $\left./ \mathrm{mL}\right)$, except for BoHE at 150 $\mathrm{mg} / \mathrm{kg}$. The number of PMN remained high $24 \mathrm{~h}$ after Mabs inoculation $\left(8.02 \pm 1.7 \times 10^{5}\right.$ cells $\left./ \mathrm{mL}\right)$ and was reduced in animals treated with the extracts, particularly those treated with $50 \mathrm{mg} / \mathrm{kg}\left(0.3 \pm 0.12 \times 10^{5}\right.$ cells $\left./ \mathrm{mL}\right)$ and $150 \mathrm{mg} / \mathrm{Kg}(0.69$ $\pm 0.51 \times 10^{5}$ cells $\left./ \mathrm{mL}\right)$ BoEA. These results were similar to those observed in dexamethasone-treated animals $(0.3 \pm 0.04$ $\times 10^{5}$ cells $/ \mathrm{mL}$ ) (Figure 3(d)).

Finally, the effects of BoEA and BoHE on mononuclear cells (MNs) migration induced by Mabs inoculation were also determined (Figures 3(e) and 3(f)). At $4 \mathrm{~h}$ after the 


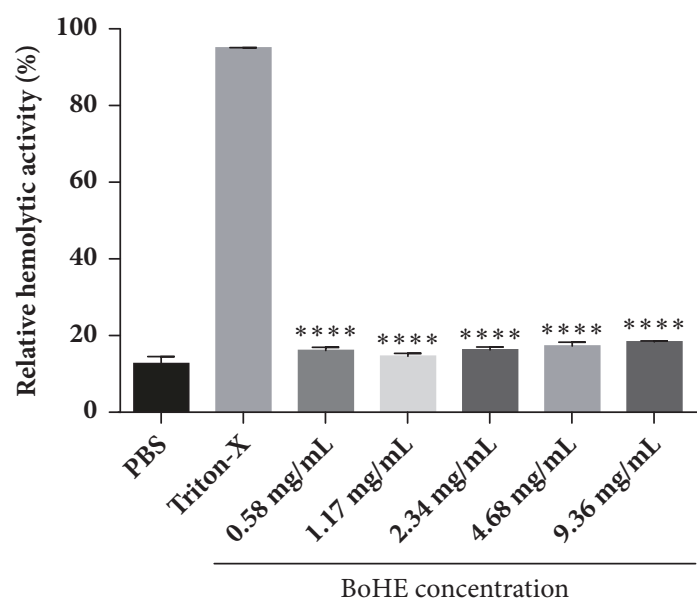

(a)

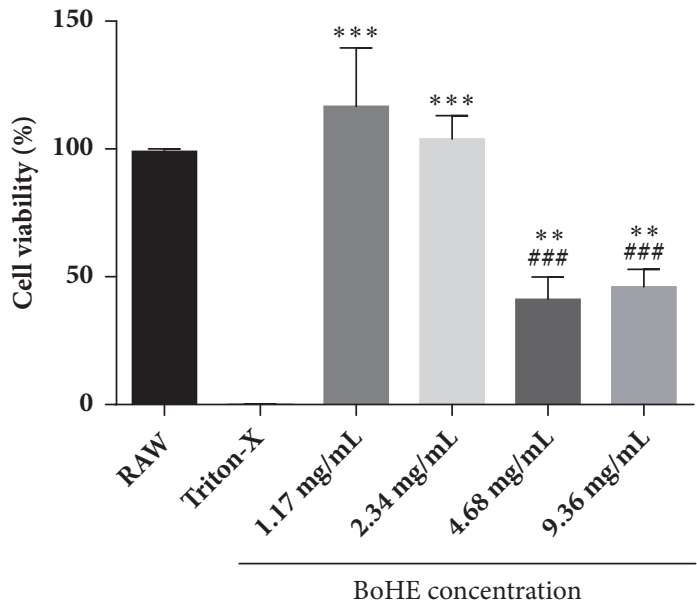

(c)

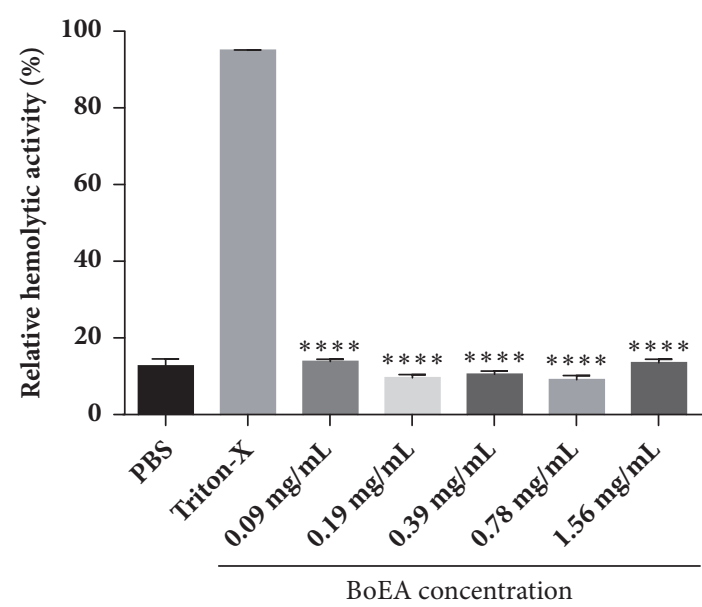

(b)

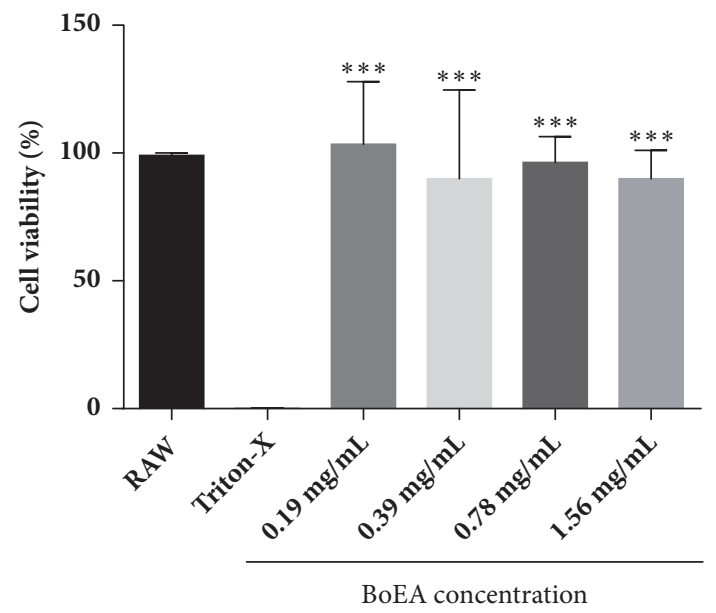

(d)

Figure 1: Cytotoxic effects of Bixa orellana leaves extracts (BoHE and BoEA). (a), (b) Hemolytic activity of Bixa orellana leaves extracts (BoHE and BoEA) performed with type A, B, and O human erythrocytes. (c), (d) Cytotoxicity of Bixa orellana leaves extract (BoHE and BoEA) towards RAW 264.7 cells determined by MTT assay. Results are means \pm standard deviation of the results in triplicate. ${ }^{\# \#} \mathrm{p}<0.0005$ compared with untreated cells. $* * \mathrm{p}<0.005 ; * * * \mathrm{p}<0.0005$ compared with Triton $\mathrm{X}$. Each assay was performed in triplicate, and each experiment was repeated three times.

induction of peritonitis, the number of PMN was higher in the Mabs $\left(8.04 \pm 1.47 \times 10^{5}\right.$ cells $\left./ \mathrm{mL}\right)$ than in the saline group $\left(1.44 \pm 0.19 \times 10^{5}\right.$ cells $/ \mathrm{mL}$ ) (Figure $3(\mathrm{e})$ ). MN migration was inhibited most strongly in animals pretreated with $50 \mathrm{mg} / \mathrm{kg}$ BoEA $\left(0.51 \pm 0.03 \times 10^{5}\right.$ cells $\left./ \mathrm{mL}\right)$, followed by the doses of $150 \mathrm{mg} / \mathrm{kg}$ BoEA $\left(0.96 \pm 0.45 \times 10^{5}\right.$ cells $\left./ \mathrm{mL}\right), 50 \mathrm{mg} / \mathrm{kg}$ BoHE (1.17 $\pm 1.03 \times 10^{5}$ cells $\left./ \mathrm{mL}\right)$, and $150 \mathrm{mg} / \mathrm{kg} \mathrm{BoHE}$ $\left(3.03 \pm 0.9 \times 10^{5}\right.$ cells $\left./ \mathrm{mL}\right)$. As shown in Figure $3(\mathrm{f})$, this effect continued through $24 \mathrm{~h}$, when inhibition was strongest in the pretreatment with $50 \mathrm{mg} / \mathrm{kg}$ BoEA $(0.32 \pm 0.02 \mathrm{x}$ $10^{5}$ cells $\left./ \mathrm{mL}\right)$, followed by $50 \mathrm{mg} / \mathrm{kg}$ BoHE $\left(0.75 \pm 0.21 \times 10^{5}\right.$ cells $/ \mathrm{mL}), 150 \mathrm{mg} / \mathrm{kg}$ BoEA $\left(0.81 \pm 0.54 \times 10^{5}\right.$ cells $\left./ \mathrm{mL}\right)$, and $\operatorname{BoHE}\left(0.92 \pm 0.1 \times 10^{5}\right.$ cells $\left./ \mathrm{mL}\right)$.

3.5. Acute Toxicity. The evaluation of acute toxicity included the histological evaluation of esophagus, stomach, liver, and kidney tissue samples from all experimental groups used in this study. No significant histological changes were observed at either $4 \mathrm{~h}$ or $24 \mathrm{~h}$. Normal tissue and organ structures were maintained (Figures 4 and 5). The maintenance of esophageal and gastric mucosa confirmed the satisfactory performance of the therapeutic gavage protocol. The architecture of the evaluated organ tissues was preserved, with normal histological characteristics.

3.6. HPLC-MS Analysis of BoEA. Figure 6 illustrates the HPLC-DAD chromatogram of the phenolic compounds from ethyl acetate phase from hydroalcoholic extract from leaves of $B$. orellana. A total of nine peaks corresponding to compounds 1-9 were tentatively identified on the basis of their retention times and MS pattern with also taking into account data in the related literature. These compounds included procyanidin B-2 and B-3, granatin B, neostrictinin, ellagitannin isomer, kaempferol-3-O- $\beta$-D-6-(p-coumaroyl) 


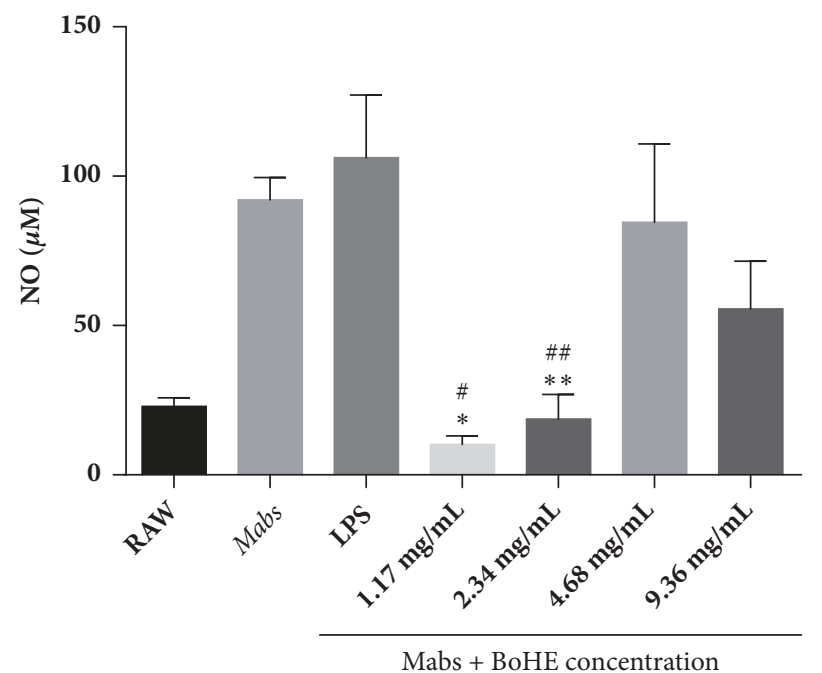

(a)

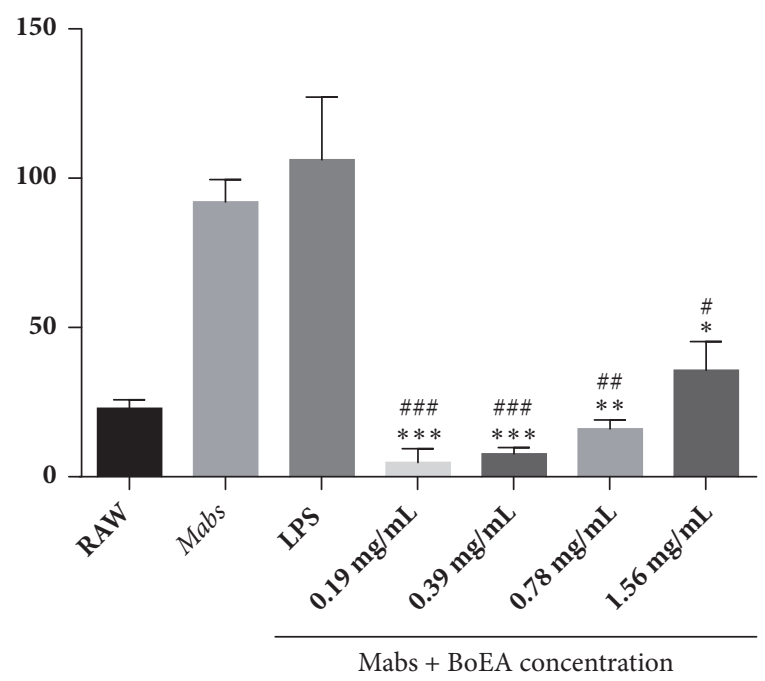

(b)

Figure 2: Effects of B. orellana leaves extract (BoHE and BoEA) on NO production by murine RAW 264.7 cells after infection with $M$. abscessus (Mabs). To evaluate NO production, RAW 264.7 cells were infected with $1 \times 10^{8}$ CFU of Mabs, followed by treatment with BoHE or BoEA. Results are means \pm standard deviation of the results in triplicate. $* \mathrm{p}<0.05 ; * * \mathrm{p}<0.005 ; * * \mathrm{p}<0.0005$ compared with the LPS control. The assay was performed in triplicate, and the experiment was repeated three times.

TABLE 1: Spectrometric data of phenolic compounds identified in the ethyl acetate extract of Bixa orellana leaves (BoEA).

\begin{tabular}{lcccc}
\hline Peak & $\mathbf{R}_{\mathbf{t}}$ & Compound & {$[\mathbf{M}-\mathbf{H}]^{-}$} & MS $^{\mathbf{n}}$ fragments \\
\hline 1 & 12.8 & procyanidin B-2 & 577 & $559,451,425,407,289$ \\
2 & 14.5 & procyanidin B-3 & 577 & $559,451,425,407,289$ \\
3 & 16.5 & granatin B & 951 & 933 \\
4 & 23.1 & neostrictinin & 633 & $463,301,275$ \\
5 & 26.3 & ellagitannin isomer & 953 & 935,301 \\
6 & 31.0 & kaempferol-3-O- $\beta$-D-6-(p-coumaroyl) glucopyranoside & 593 & 285 \\
7 & 33.1 & ellagic acid glucoside & 463 & 301 \\
8 & 38.1 & kaempferol-3-O-D-glucoside & 447 & 285 \\
9 & 39.0 & ellagic acid deoxyhexose & 477 & 301 \\
\hline
\end{tabular}

$\mathrm{R}_{\mathrm{t}}$ expressed in min; $[\mathrm{M}-\mathrm{H}]^{-}$and $\mathrm{MS}^{\mathrm{n}}$ fragments in $m / z$.

glucopyranoside, ellagic acid glucoside, kaempferol-3-O-Dglucoside, and ellagic acid deoxyhexose as shown in Table 1.

\section{Discussion}

This study evaluated the antimicrobial and anti-inflammatory activities of $B$. orellana, a species widely used in folk medicine for the treatment of infections, headache, dysentery, fever, indigestion, and skin diseases $[29,30]$. The tested $B$. orellana extracts had antimicrobial activity against $M$. abscessus. Although $B$. orellana is widely used to treat respiratory infections, this is the first report of its kind. The study results are consistent with a previous study reporting MIC values of $0.3,0.5$, and $0.2 \mathrm{mg} / \mathrm{mL}$ for $B$. orellana leaf, seed, and root extracts against $M$. tuberculosis [31]. Only few studies have described the antimycobacterial activity of plant-derived products against $M$. abscessus, for example, the effects of chloroform and ethanolic extracts from seeds of Persea americana (where the activity of the extracts was associated with lignans) [32], Valencia orange terpeneless oil [33], and Pelargonium reniforme and P. sidoides root extracts (containing linear chain fatty acids such as palmitic, oleic, and linoleic) [34].

Inflammatory responses play important roles in host defense and also contribute to immunopathogenesis during mycobacterial infection [35]. M. abscessus is a respiratory pathogen causing chronic lung diseases and infections associated with cystic fibrosis [36]. A strain of M. abscessus forms colonies with rough morphology and is known to induce inflammatory responses associated with invasive disease [37]. The anti-inflammatory activity of BoHE and BoEA was evaluated in a C57BL/6 mouse model of peritonitis induced by heat killed M. abscessus. M. abscessus is an etiological agent of infections associated with laparoscopic gastric bands [38] and causes acute peritonitis that can evolve with ascites and formation of granulomas [39].

In the study model, oral pretreatment with BoHE or BoEA (both at $50 \mathrm{mg} / \mathrm{kg}$ or $150 \mathrm{mg} / \mathrm{kg}$ ) significantly reduced 


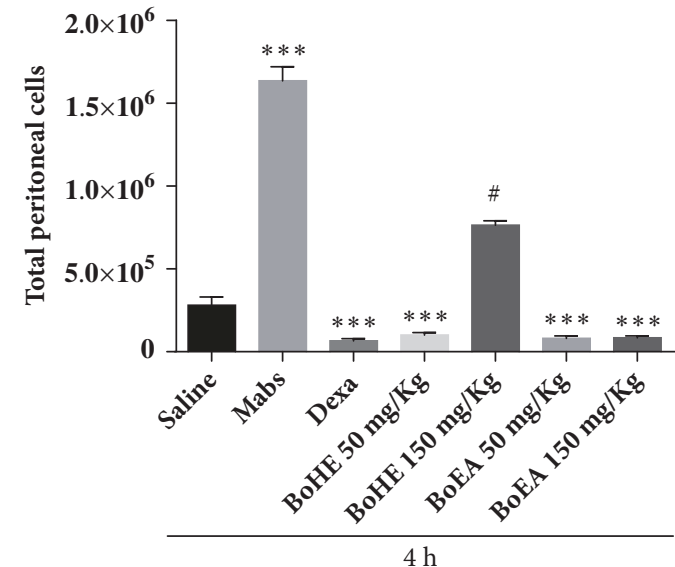

(a)

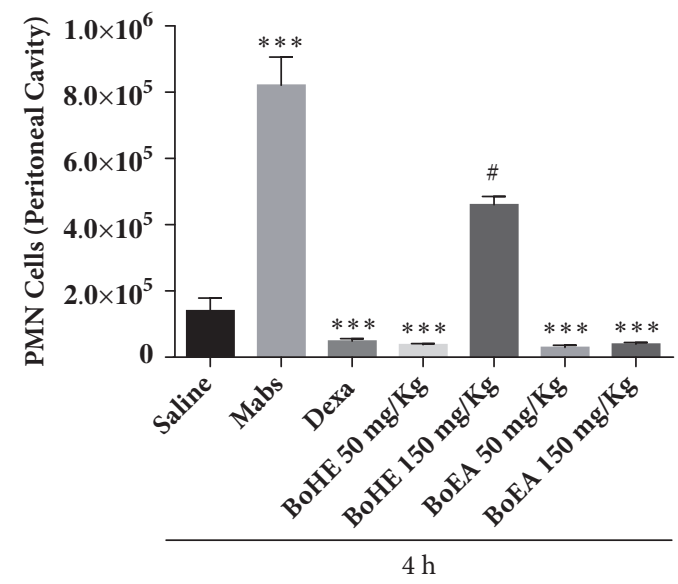

(c)

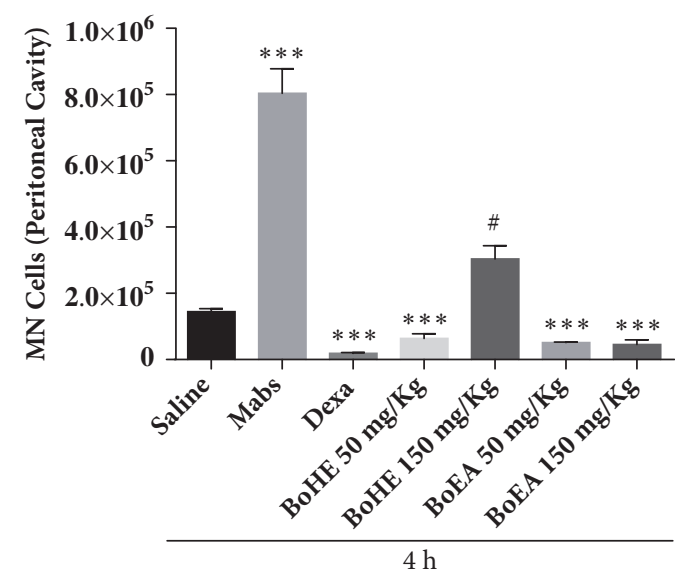

(e)

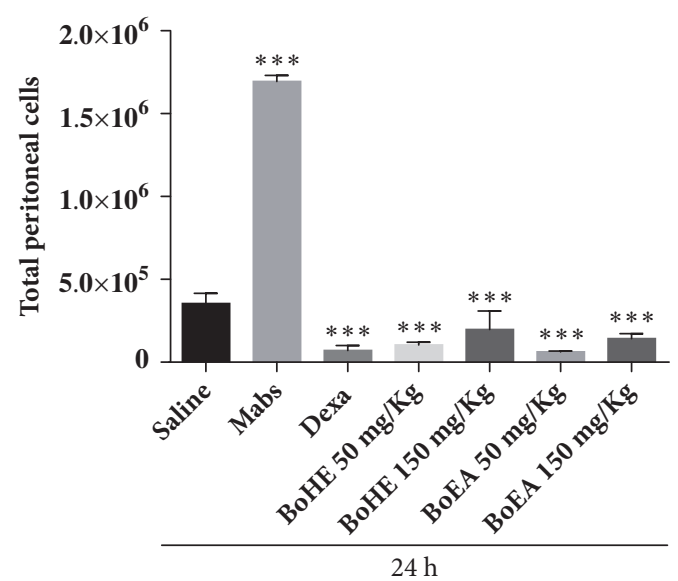

(b)

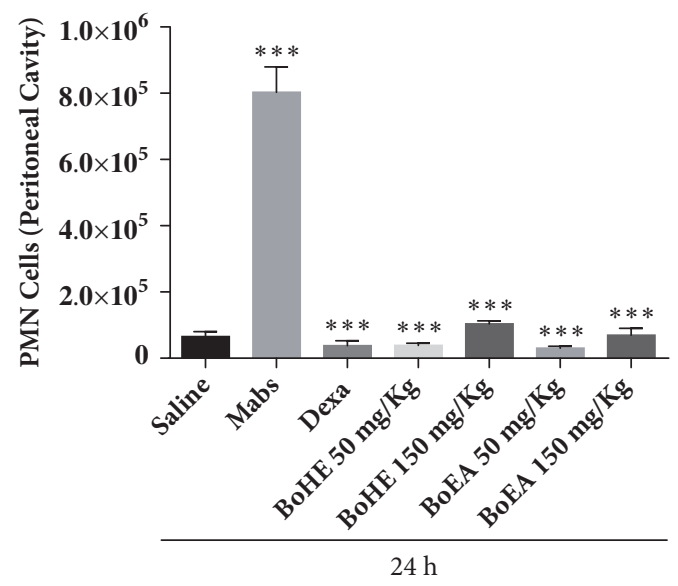

(d)

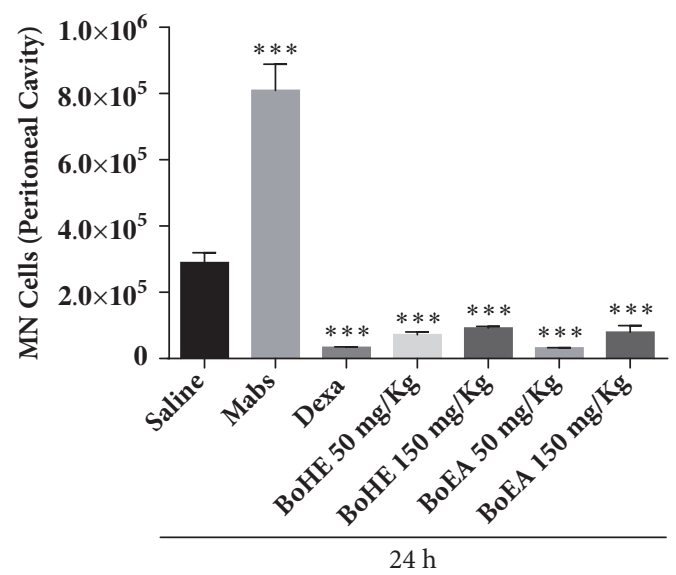

(f)

FIGURE 3: Effects of Bixa orellana extracts (BoHE and BoEA) on cell migration to peritoneal fluid after induction of peritonitis by heat killed M. abscessus (Mabs). Saline: animals treated with $0.9 \%$ saline solution $(1 \mathrm{~mL} / \mathrm{kg}$ ) without Mabs inoculation (negative control); Mabs: animals treated with $0.9 \%$ saline solution $(1 \mathrm{~mL} / \mathrm{kg}$ ) and inoculated with $M a b s$; Dexa: animals treated with $5 \mathrm{mg} / \mathrm{kg}$ dexamethasone and inoculated with Mabs; BoHE $50 \mathrm{mg} / \mathrm{kg}$ : animals treated with $50 \mathrm{mg} / \mathrm{kg}$ BoHE and inoculated with Mabs; BoHE $150 \mathrm{mg} / \mathrm{kg}$ : animals treated with 150 $\mathrm{mg} / \mathrm{kg}$ BoHE and inoculated with Mabs; BoEA $50 \mathrm{mg} / \mathrm{kg}$ : animals treated with $50 \mathrm{mg} / \mathrm{kg}$ BoEA and inoculated with Mabs; BoEA $150 \mathrm{mg} / \mathrm{kg}$ : animals treated with $150 \mathrm{mg} / \mathrm{kg}$ BoEA and inoculated with Mabs. (a) Total leukocytes $4 \mathrm{~h}$ after induction of peritonitis. (b) Total leukocytes $24 \mathrm{~h}$ after induction of peritonitis. (c) Polymorphonuclear cells (PMN) 4h after induction of peritonitis. (d) Polymorphonuclear cells (PMN) 24h after induction of peritonitis. (e) Mononuclear cells (MN) 4h after induction of peritonitis. (f) Mononuclear cells (MN) 24h after induction of peritonitis. $* * * \mathrm{p}<0.001$ compared with Mabs controls. ${ }^{*} \mathrm{p}<0.001$ compared with saline controls. 


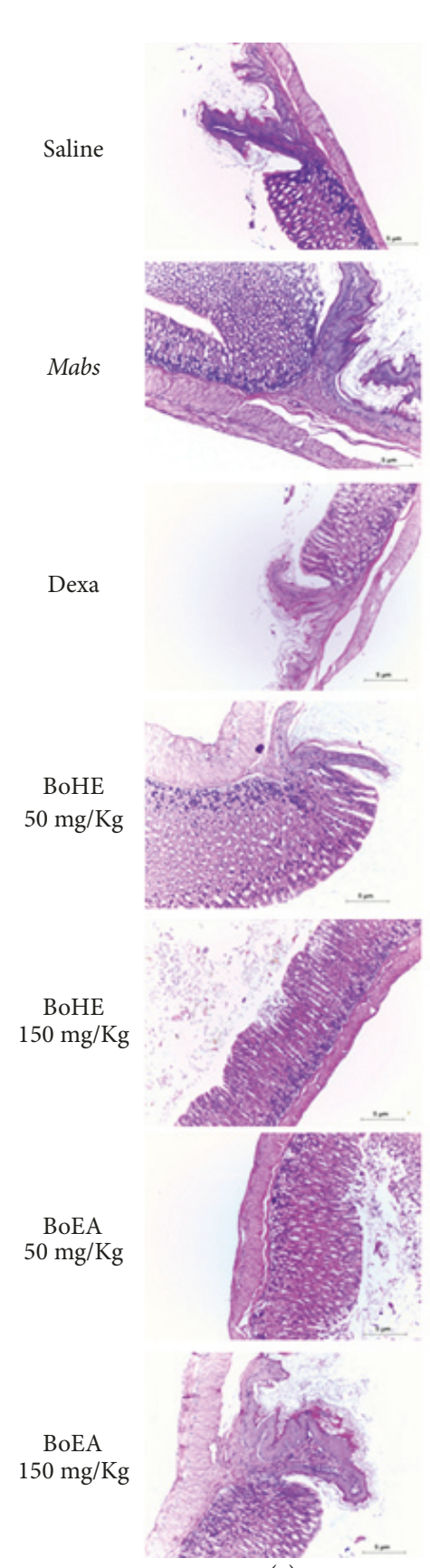

(a)
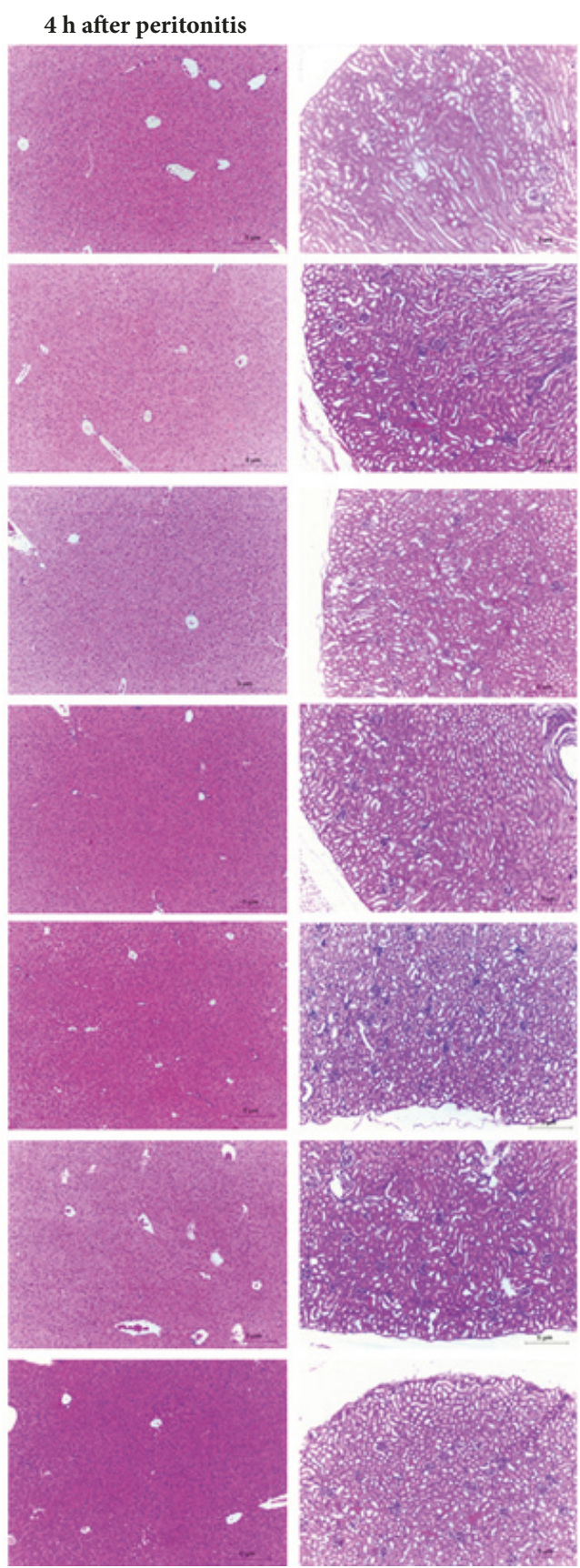

(b)
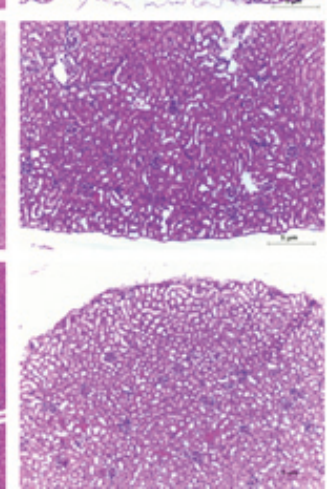

(c)

FIGURE 4: Evaluation of the toxicity of Bixa orellana extracts (BoHE and BoEA) in C57BL/6 mice $4 \mathrm{~h}$ after induction of peritonitis. Saline: animals treated with $0.9 \%$ saline solution $(1 \mathrm{~mL} / \mathrm{kg}$ ) without Mabs inoculation (negative control); Mabs: animals treated with $0.9 \%$ saline solution ( $1 \mathrm{~mL} / \mathrm{kg}$ ) and inoculated with Mabs; Dexa: animals treated with $5 \mathrm{mg} / \mathrm{kg}$ dexamethasone and inoculated with $\mathrm{Mabs}$; BoHE $50 \mathrm{mg} / \mathrm{kg}$ : animals treated with $50 \mathrm{mg} / \mathrm{kg}$ BoHE and inoculated with Mabs; BoHE $150 \mathrm{mg} / \mathrm{kg}$ : animals treated with $150 \mathrm{mg} / \mathrm{kg}$ BoHE and inoculated with Mabs; BoEA $50 \mathrm{mg} / \mathrm{kg}$ : animals treated with $50 \mathrm{mg} / \mathrm{kg}$ BoEA and inoculated with Mabs; BoEA $150 \mathrm{mg} / \mathrm{kg}$ : animals treated with $150 \mathrm{mg} / \mathrm{kg}$ BoEA and inoculated with Mabs. Column (A): esophageal/stomach transition area with no significant histological changes. Column (B): liver histology has a normal appearance. Column (C): kidney histology has a normal appearance. H\&E stain, $\times 100$.

the migration of leukocytes to the peritoneal cavity. The observation that the effects were similar to those observed with the anti-inflammatory dexamethasone suggests that the extracts had secondary metabolites with anti-inflammatory activity. The anti-inflammatory activity of $B$. orellana-derived products has been previously reported [19, 20, 40].

In this study, BoHE and BoEA reduced NO production in Mabs-infected RAW 264.7 murine macrophages. It has 


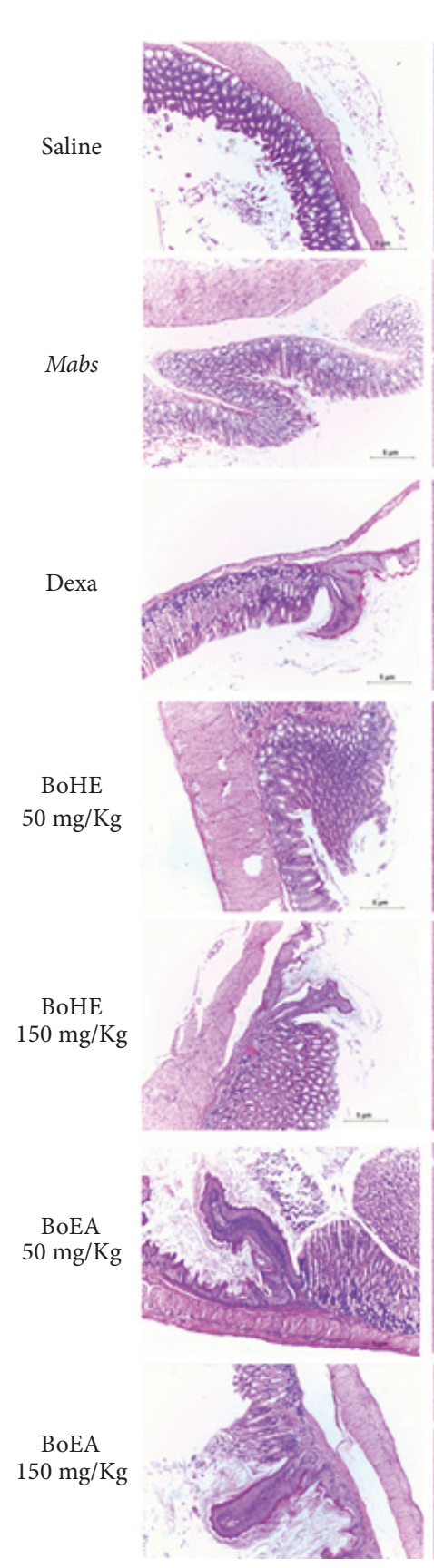

(a)
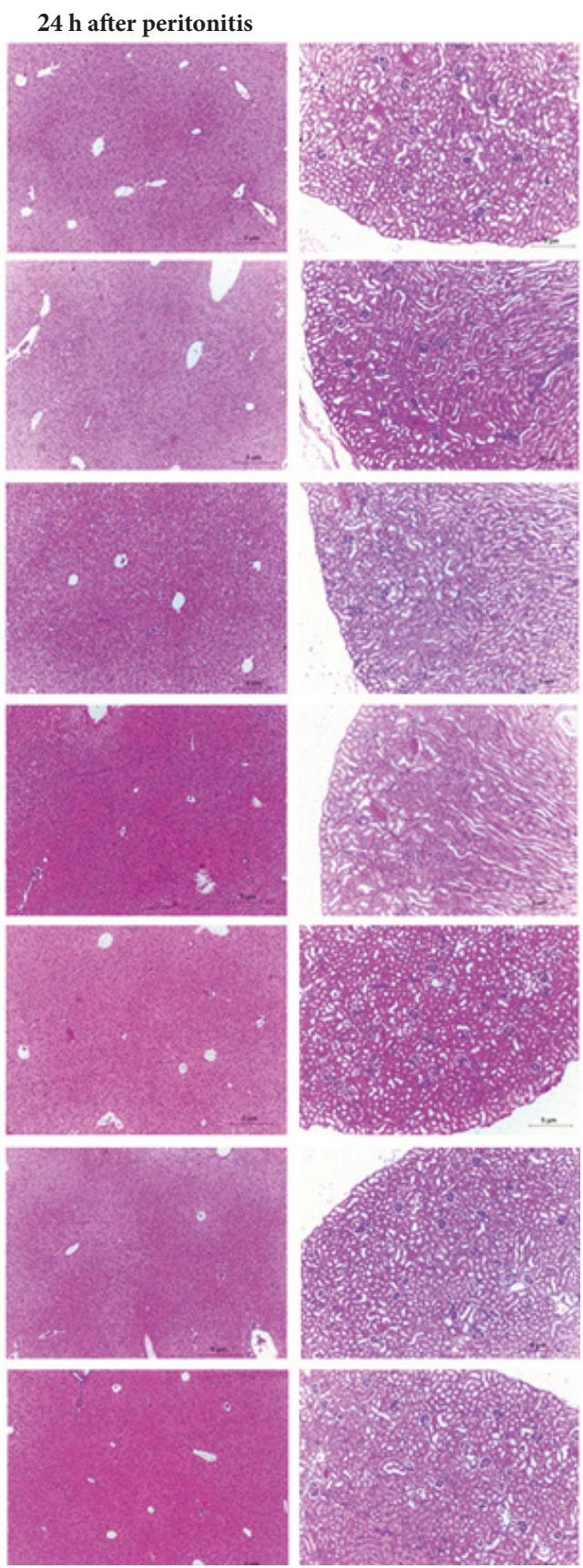

(b)
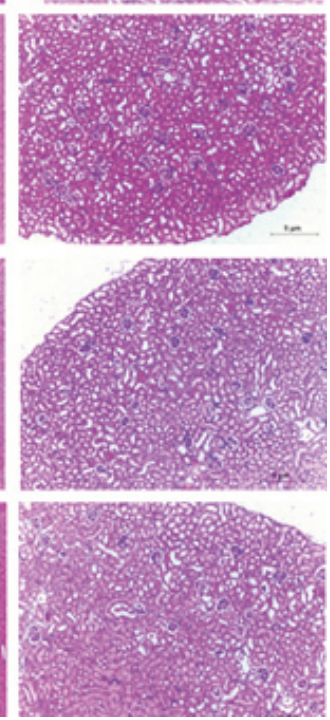

(c)

FIGURE 5: Evaluation of the toxicity of Bixa orellana extracts (BoHE and BoEA) in C57BL/6 mice $24 \mathrm{~h}$ after induction of peritonitis. Saline: animals treated with $0.9 \%$ saline solution $(1 \mathrm{~mL} / \mathrm{kg}$ ) without Mabs inoculation (negative control); Mabs: animals treated with $0.9 \%$ saline solution ( $1 \mathrm{~mL} / \mathrm{kg}$ ) and inoculated with Mabs; Dexa: animals treated with $5 \mathrm{mg} / \mathrm{kg}$ dexamethasone and inoculated with $\mathrm{Mabs}$; BoHE $50 \mathrm{mg} / \mathrm{kg}$ : animals treated with $50 \mathrm{mg} / \mathrm{kg}$ BoHE and inoculated with Mabs; BoHE $150 \mathrm{mg} / \mathrm{kg}$ : animals treated with $150 \mathrm{mg} / \mathrm{kg} \mathrm{BoHE}$ and inoculated with Mabs; BoEA $50 \mathrm{mg} / \mathrm{kg}$ : animals treated with $50 \mathrm{mg} / \mathrm{kg}$ BoEA and inoculated with Mabs; BoEA $150 \mathrm{mg} / \mathrm{kg}$ : animals treated with $150 \mathrm{mg} / \mathrm{kg}$ BoEA and inoculated with Mabs. Column (A): esophageal/stomach transition area with no significant histological changes. Column (B): liver histology has a normal appearance. Column (C): kidney histology has a normal appearance. H\&E stain, $\times 100$.

been shown that peritoneal macrophages of C57BL/6 mice produce high levels of $\mathrm{NO}$ after infection with $M$. abscessus [41]. NO produced by activated cells has cytotoxic and microbicidal action that promotes the destruction of invading microorganisms [42]. BoHE and BoEA might reduce NO production by inhibiting enzymes responsible for the production of induced nitric oxide synthase (iNOS) [43].

The migration of leukocytes into inflamed tissue from the microcirculation is characteristic of acute inflammation [44]. The anti-inflammatory activity of BoHE and BoEA extracts 


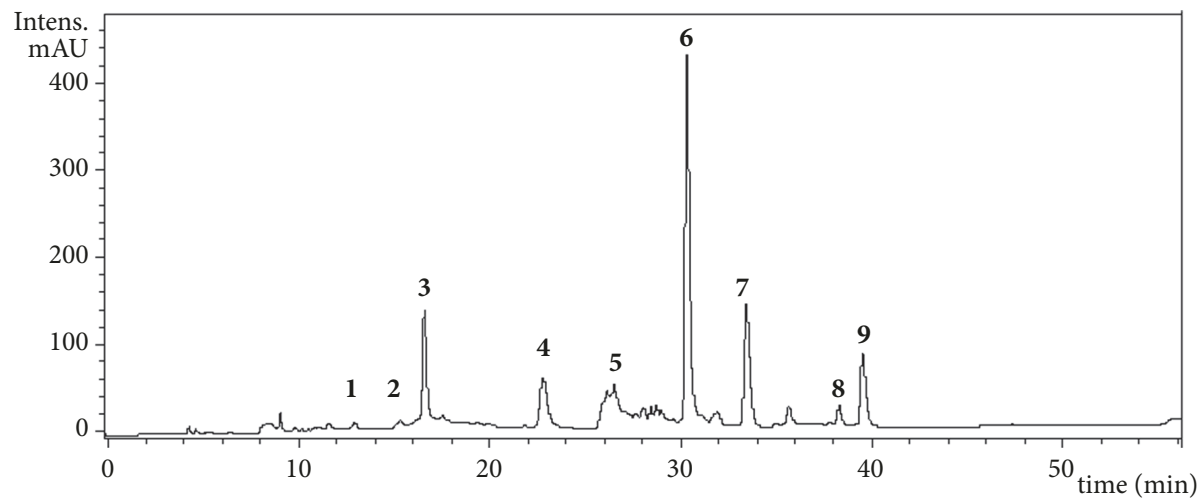

FIgURE 6: HPLC/DAD chromatogram of the acetyl acetate extract of Bixa orellana leaves (BoEA) monitored at $254 \mathrm{~nm}$. Structure of constituents identified by HPLC3 DAD-ESI-IT/MS. ID: identification; RT: retention time; MS: mass spectrometer.

was evaluated in a model of peritonitis induced by heat killed M. abscessus in which treatment with the extracts reduced the peritoneal migration of leukocytes. The BoHE and BoEA extracts were both protective against the development of acute inflammation in the mouse model used in this study. The $B$. orellana active extract contained several flavonoids, such as kaempferol, ellagic acid, and HHDP glucose, which are known immunomodulators [45-49].

Determining the toxicity of natural products with therapeutic potential is fundamental to the investigation of their bioactive potential. Effective and safe therapeutics are more active against pathological agents than the cells and tissues of the organism being treated. Histological analysis of esophagus, stomach, liver, and kidney tissue confirmed that the BoHE and BoEA treatment regimens, the concentration, the route of administration, and the exposure time were neither hepatotoxic nor nephrotoxic. These are essential criteria when evaluating new therapeutic compounds. Oral administration, as used in this study, did not disturb the normal histology of the esophageal or gastric mucosa. The absence of mucosal damage allows for drug absorption and satisfactory biotransformation, both of which are essential [50].

\section{Conclusions}

The extracts of $B$. orellana leaves (BoHE and BoEA) had antimicrobial activity against $M$. abscessus subsp. massiliense and low toxicity against murine RAW 264.7 cells. The antimycobacterial activity was accompanied by significant anti-inflammatory activity in a peritonitis model induced by $M$. abscessus subsp. massiliense in mice. Inhibition of the migration of leukocytes to the site of inflammation was associated with secondary metabolites. The extracts did not cause acute toxicity in the evaluated organs. Taken together, the results of the study demonstrated the antimicrobial and anti-inflammatory potential of the BoHE and BoEA extracts of $B$. orellana, which makes these natural compounds targets for drug development. Further in vivo studies of the antimicrobial effect of BoHE and BoEA are warranted.

\section{Data Availability}

The values used to build graphs to support the findings of this study are available from the corresponding author upon request.

\section{Conflicts of Interest}

The authors declare no conflicts of interest.

\section{Authors' Contributions}

Eduardo Martins de Sousa and Lídio Gonçalves Lima Neto conceptualized and designed the study. José Lima Viana, Adrielle Zagmignan, Cristina de Andrade Monteiro, Letícia Machado Gonçalves, and Luís Felipe Lima Lobato performed the research. Lídio Gonçalves Lima Neto, Adrielle Zagmignan, José Lima Viana, Luís Felipe Lima Lobato, Afonso Gomes Abreu Junior, Luís Cláudio Nascimento da Silva, Joicy Cortez de Sá, João Henrique Ghilardi Lago, Rafael Cardoso Carvalho, and Eduardo Martins de Sousa carried out the data analysis. Lídio Gonçalves Lima Neto, Adrielle Zagmignan, José Lima Viana, Luís Felipe Lima Lobato, Afonso Gomes Abreu Junior, Luís Cláudio Nascimento da Silva, Joicy Cortez de Sá, João Henrique Ghilardi Lago, and Eduardo Martins de Sousa wrote the manuscript.

\section{Acknowledgments}

This work received financial support from FAPEMA (REBAX03628/13; BM-01281/15; UNIVERSAL-01468/16; COOPI02860/16; UNIVERSAL-00998/16) and Ceuma University.

\section{References}

[1] S. C. Leao, E. Tortoli, J. Paul Euzé, and M. J. Garcia, "Proposal that Mycobacterium massiliense and Mycobacterium bolletii be united and reclassified as Mycobacterium abscessus subsp. bolletii comb. nov., designation of Mycobacterium abscessus subsp. abscessus subsp. nov. and emended description of 
Mycobacterium abscessus," International Journal of Systematic and Evolutionary Microbiology, vol. 61, no. 9, pp. 2311-2313, 2011.

[2] Y.-J. Cho, H. Yi, J. Chun et al., "The genome sequence of 'Mycobacterium massiliense' strain CIP 108297 suggests the independent taxonomic status of the Mycobacterium abscessus complex at the subspecies level," PLoS ONE, vol. 8, no. 11, 2013.

[3] E. D. Chan, X. Bai, M. Kartalija, I. M. Orme, and D. J. Ordway, "Host immune response to rapidly growing mycobacteria, an emerging cause of chronic lung disease," American Journal of Respiratory Cell and Molecular Biology, vol. 43, no. 4, pp. 387393, 2010.

[4] J. M. Bryant, D. M. Grogono, D. Greaves et al., "Wholegenome sequencing to identify transmission of Mycobacterium abscessus between patients with cystic fibrosis: a retrospective cohort study," The Lancet, vol. 381, no. 9877, pp. 1551-1560, 2013.

[5] D. E. Griffith, T. Aksamit, B. A. Brown-Elliott et al., "An official ATS/IDSA statement: diagnosis, treatment, and prevention of nontuberculous mycobacterial diseases," American Journal of Respiratory and Critical Care Medicine, vol. 175, no. 4, pp. 367416, 2007.

[6] R. Nessar, E. Cambau, J. M. Reyrat, A. Murray, and B. Gicquel, "Mycobacterium abscessus: A new antibiotic nightmare," Journal of Antimicrobial Chemotherapy, vol. 67, no. 4, Article ID dkr578, pp. 810-818, 2012.

[7] H. Kameyama, Y. Mori, T. Kimura et al., "A case report of mycobacterium abscessus peritonitis in a peritoneal dialysis patient," Therapeutic Apheresis and Dialysis, vol. 11, no. 6, pp. 449-451, 2007.

[8] J. O. Falkinham, "Mycobacterial aerosols and respiratory disease," Emerging Infectious Diseases, vol. 9, no. 7, pp. 763-767, 2003.

[9] H. Medjahed, J.-L. Gaillard, and J.-M. Reyrat, "Mycobacterium abscessus: a new player in the mycobacterial field," Trends in Microbiology, vol. 18, no. 3, pp. 117-123, 2010.

[10] S. Chopra, K. Matsuyama, C. Hutson, and P. Madrid, "Identification of antimicrobial activity among FDA-approved drugs for combating Mycobacterium abscessus and Mycobacterium chelonae," Journal of Antimicrobial Chemotherapy, vol. 66, no. 7, Article ID dkr154, pp. 1533-1536, 2011.

[11] S. Bastian, N. Veziris, A.-L. Roux et al., "Assessment of clarithromycin susceptibility in strains belonging to the Mycobacterium abscessus group by erm (41) and rrl sequencing," Antimicrobial Agents and Chemotherapy, vol. 55, no. 2, pp. 775781, 2011.

[12] S. J. Shallom, N. S. Moura, K. N. Olivier, E. P. Sampaio, S. M. Holland, and A. M. Zelazny, "New real-time PCR assays for detection of inducible and acquired clarithromycin resistance in the mycobacterium abscessus group," Journal of Clinical Microbiology, vol. 53, no. 11, pp. 3430-3437, 2015.

[13] F. Mougari, R. Amarsy, N. Veziris et al., "Standardized interpretation of antibiotic susceptibility testing and resistance genotyping for Mycobacterium abscessus with regard to subspecies and erm41 sequevar," Journal of Antimicrobial Chemotherapy, vol. 71, no. 8, pp. 2208-2212, 2016.

[14] A. Vilar Dde, M. S. Vilar, T. F. de Lima e Moura et al., "Traditional uses, chemical constituents, and biological activities of Bixa orellana L.: A Review," The Scientific World Journal, vol. 2014, Article ID 857292, 11 pages, 2014.

[15] J. J. Rojas, V. J. Ochoa, S. A. Ocampo, and J. F. Muñoz, "Screening for antimicrobial activity of ten medicinal plants used in Colombian folkloric medicine: a possible alternative in the treatment of non-nosocomial infections," BMC Complementary and Alternative Medicine, vol. 6, article no. 2, 2006.

[16] D. Medina-Flores, G. Ulloa-Urizar, R. Camere-Colarossi, S. Caballero-García, F. Mayta-Tovalino, and J. del Valle-Mendoza, "Antibacterial activity of Bixa orellana L. (achiote) against Streptococcus mutans and Streptococcus sanguinis," Asian Pacific Journal of Tropical Biomedicine, vol. 6, no. 5, pp. 400-403, 2016.

[17] T. V. Cuong and K. B. Chin, "Effects of annatto (Bixa orellana L.) seeds powder on physicochemical properties, antioxidant and antimicrobial activities of pork patties during refrigerated storage," Korean Journal for Food Science of Animal Resources, vol. 36, no. 4, pp. 476-486, 2016.

[18] B. Zhai, J. Clark, T. Ling, M. Connelly, F. Medina-Bolivar, and F. Rivas, "Antimalarial evaluation of the chemical constituents of hairy root culture of Bixa orellana L," Molecules, vol. 19, no. 1, pp. 756-766, 2014.

[19] Y. Yoke Keong, A. K. Arifah, S. Sukardi, A. H. Roslida, M. N. Somchit, and A. Zuraini, "Bixa orellana leaves extract inhibits bradykinin-induced inflammation through suppression of nitric oxide production," Medical Principles and Practice, vol. 20, no. 2, pp. 142-146, 2011.

[20] Y. K. Yong, N. Sulaiman, M. N. Hakim et al., "Suppressions of serotonin-induced increased vascular permeability and leukocyte infiltration by Bixa orellana leaf extract," BioMed Research International, vol. 2013, Article ID 463145, 7 pages, 2013.

[21] A. M. Cardoso, E. Martins de Sousa, C. Viana-Niero et al., "Emergence of nosocomial Mycobacterium massiliense infection in Goiás, Brazil," Microbes and Infection, vol. 10, no. 14-15, pp. 1552-1557, 2008.

[22] E. W. Coronado-Aceves, J. J. Sánchez-Escalante, J. LópezCervantes et al., "Antimycobacterial activity of medicinal plants used by the Mayo people of Sonora, Mexico," Journal of Ethnopharmacology, vol. 190, pp. 106-115, 2016.

[23] N. F. Garcia de Carvalho, D. N. Sato, F. R. Pavan, L. Ferrazoli, and E. Chimara, "Resazurin microtiter assay for clarithromycin susceptibility testing of clinical isolates of mycobacterium abscessus group," Journal of Clinical Laboratory Analysis, vol. 30, no. 5, pp. 751-755, 2016.

[24] A. P. Silva, L. C. Nascimento da Silva, C. S. Martins da Fonseca et al., "Antimicrobial activity and phytochemical analysis of organic extracts from cleome spinosa Jaqc," Frontiers in Microbiology, vol. 7, p. 963, 2016.

[25] T. Mosmann, "Rapid colorimetric assay for cellular growth and survival: application to proliferation and cytotoxicity assays," Journal of Immunological Methods, vol. 65, no. 1-2, pp. 55-63, 1983.

[26] G. T. Kim, N. K. Tran et al., "Immunomodulatory efficacy of standardized Annona muricata (Graviola) leaf extract via activation of mitogen-activated protein kinase pathways in RAW 264.7 macrophages," Evidence-Based Complementary and Alternative Medicine, vol. 2016, Article ID 2905127, 10 pages, 2016.

[27] A. J. M. C. R. Pinheiro, J. S. Gonçalves, Á. W. A. Dourado et al., "Punica granatum L. leaf extract attenuates lung inflammation in mice with acute lung injury," Journal of Immunology Research, vol. 2018, Article ID 6879183, 11 pages, 2018.

[28] G. A. Pankey and L. D. Sabath, "Clinical relevance of bacteriostatic versus bactericidal mechanisms of action in the treatment of gram-positive bacterial infections," Clinical Infectious Diseases, vol. 38, no. 6, pp. 864-870, 2004.

[29] C. Ulbricht, R. C. Windsor, A. Brigham et al., "An evidencebased systematic review of annatto (Bixa orellana L.) by the 
natural standard research collaboration," Journal of Dietary Supplements, vol. 9, no. 1, pp. 57-77, 2012.

[30] S. J. Stohs, "Safety and efficacy of Bixa orellana (achiote, annatto) leaf extracts," Phytotherapy Research, vol. 28, no. 7, pp. 956-960, 2014.

[31] R. B. Silva, C. R. Almeida, J. M. Chavasco, and J. K. Chavasco, "Antimycobacterial activity evaluation and MIC determination of liophilizated hydroalcoholic extracts of Bixa orellana L., Bixaceae," Revista Brasileira de Farmacognosia, vol. 20, no. 2, pp. 171-174, 2010.

[32] A. Jiménez-Arellanes, J. Luna-Herrera, R. Ruiz-Nicolás, J. Cornejo-Garrido, A. Tapia, and L. Yépez-Mulia, "Antiprotozoal and antimycobacterial activities of Persea americana seeds," BMC Complementary and Alternative Medicine, vol. 13, no. 1, p. 109, 2013.

[33] P. G. Crandall, S. C. Ricke, C. A. O’Bryan, and N. M. Parrish, "In vitro effects of citrus oils against Mycobacterium tuberculosis and non-tuberculous Mycobacteria of clinical importance," Journal of Environmental Science and Health, Part B: Pesticides, Food Contaminants, and Agricultural Wastes, vol. 47, no. 7, pp. 736-741, 2012.

[34] V. Seidel and P. W. Taylor, "In vitro activity of extracts and constituents of Pelagonium against rapidly growing mycobacteria," International Journal of Antimicrobial Agents, vol. 23, no. 6, pp. 613-619, 2004.

[35] A. M. Cooper, "Cell-mediated immune responses in tuberculosis," Annual Review of Immunology, vol. 27, pp. 393-422, 2009.

[36] R. A. Floto, K. N. Olivier, L. Saiman et al., "US cystic fibrosis foundation and european cystic fibrosis society consensus recommendations for the management of non-tuberculous mycobacteria in individuals with cystic fibrosis: executive summary," Thorax, vol. 71, no. 1, pp. 88-90, 2016.

[37] A. Pawlik, G. Garnier, M. Orgeur et al., "Identification and characterization of the genetic changes responsible for the characteristic smooth-to-rough morphotype alterations of clinically persistent Mycobacterium abscessus," Molecular Microbiology, vol. 90, no. 3, pp. 612-629, 2013.

[38] H. L. Wright, R. M. Thomson, A. B. Reid et al., "Rapidly growing mycobacteria associated with laparoscopic gastric banding, Australia, 2005-2011," Emerging Infectious Diseases, vol. 20, no. 10, pp. 1612-1619, 2014.

[39] H. I. Hakami, A. A. Alhazmi, and A. A. Alrajhi, "Mycobacterium abscessus peritonitis associated with laparoscopic gastric banding," BMC Infectious Diseases, vol. 13, no. 1, p. 323, 2013.

[40] Y. K. Yong, Z. A. Zakaria, A. A. Kadir, M. N. Somchit, G. Ee Cheng Lian, and Z. Ahmad, "Chemical constituents and antihistamine activity of Bixa orellana leaf extract," $B M C$ Complementary and Alternative Medicine, vol. 13, 2013.

[41] E. Martins de Sousa, F. B. De Bortoli, E. P. Amaral et al., "Acute immune response to Mycobacterium massiliense in C57BL/6 and BALB/c mice," Infection and Immunity, vol. 78, no. 4, pp. 1571-1581, 2010.

[42] T. J. Guzik, R. Korbut, and T. Adamek-Guzik, "Nitric oxide and superoxide in inflammation and immune regulation," Journal of Physiology and Pharmacology, vol. 54, no. 4, pp. 469-487, 2003.

[43] S. Moncada and E. A. Higgs, "The discovery of nitric oxide and its role in vascular biology," British Journal of Pharmacology, vol. 147, 1, pp. S193-S201, 2006.

[44] S. Nourshargh and R. Alon, "Leukocyte migration into inflamed tissues," Immunity, vol. 41, no. 5, pp. 694-707, 2014.
[45] A. Braca, F. Dal Piaz, S. Marzocco, G. Autore, A. Vassallo, and N. de Tommasi, "Triterpene derivatives as inhibitors of protein involved in the inflammatory process: Molecules interfering with phospholipase A2, cycloxygenase, and lipoxygenase," Current Drug Targets, vol. 12, no. 3, pp. 302-321, 2011.

[46] R. T. Ferreira, M. A. S. Coutinho, D. C. Malvar et al., "Mechanisms underlying the antinociceptive, antiedematogenic, and anti-inflammatory activity of the main flavonoid from kalanchoe pinnata," Evidence-Based Complementary and Alternative Medicine, vol. 2014, Article ID 429256, 8 pages, 2014.

[47] H. P. Kim, K. H. Son, H. W. Chang, and S. S. Kang, "Antiinflammatory plant flavonoids and cellular action mechanisms," Journal of Pharmacological Sciences, vol. 96, no. 3, pp. 229-245, 2004.

[48] A. García-Lafuente, E. Guillamón, A. Villares, M. A. Rostagno, and J. A. Martínez, "Flavonoids as anti-inflammatory agents: implications in cancer and cardiovascular disease," Inflammation Research, vol. 58, no. 9, pp. 537-552, 2009.

[49] D. Cornélio Favarin, M. Martins Teixeira, E. Lemos de Andrade et al., "Anti-inflammatory effects of ellagic acid on acute lung injury induced by acid in mice," Mediators of Inflammation, vol. 2013, Article ID 164202, 13 pages, 2013.

[50] P. Manikandan and S. Nagini, "Cytochrome P450 structure, function and clinical significance: A review," Current Drug Targets, vol. 19, no. 1, pp. 38-54, 2018. 


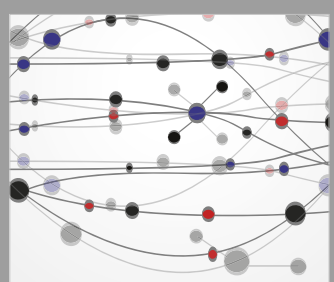

The Scientific World Journal
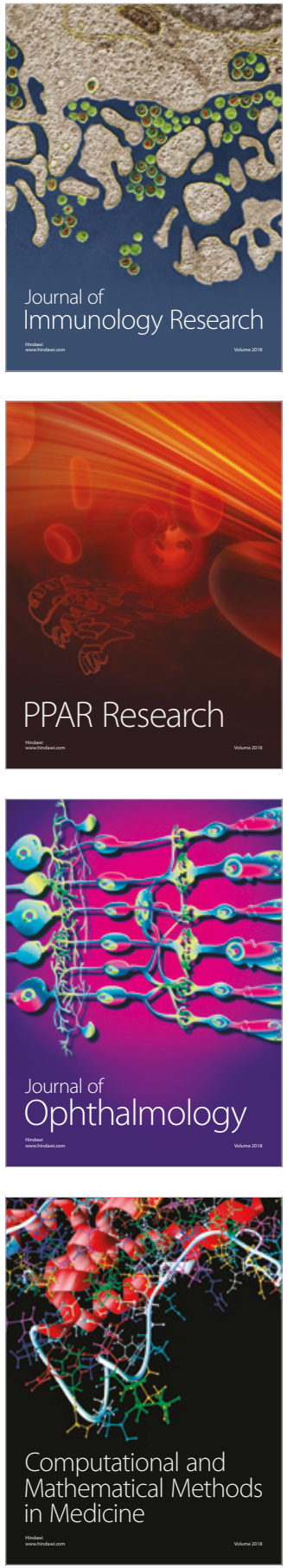

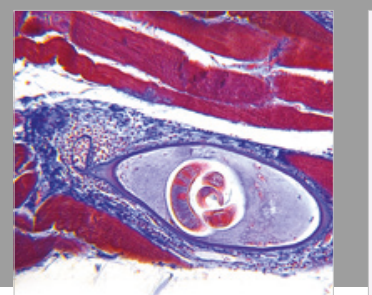

Gastroenterology Research and Practice

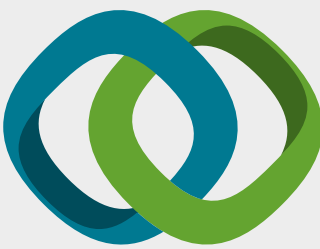

\section{Hindawi}

Submit your manuscripts at

www.hindawi.com
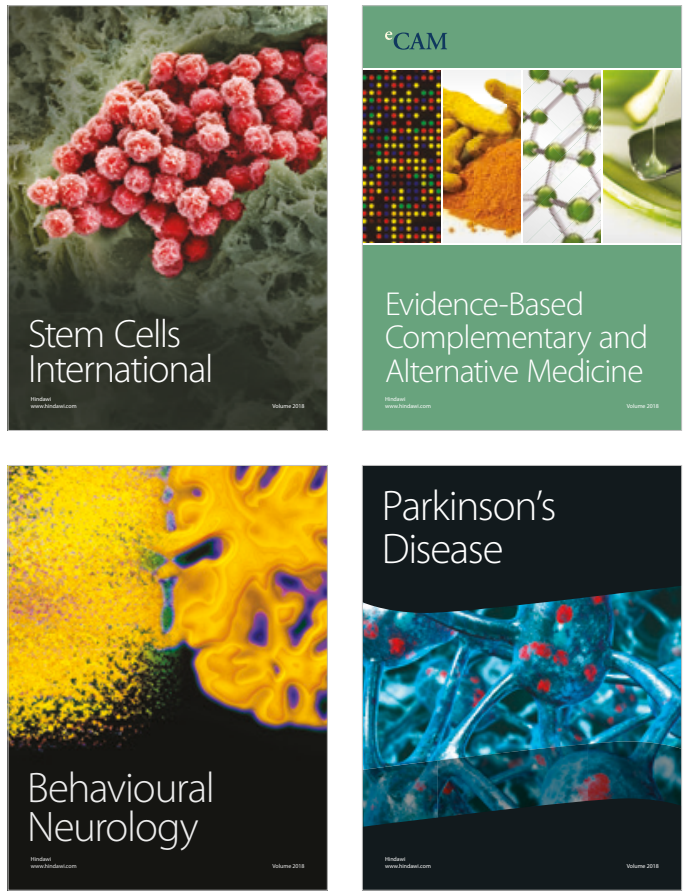

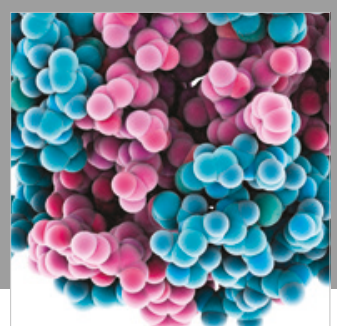

ournal of

Diabetes Research

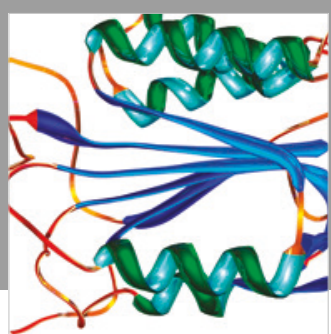

Disease Markers
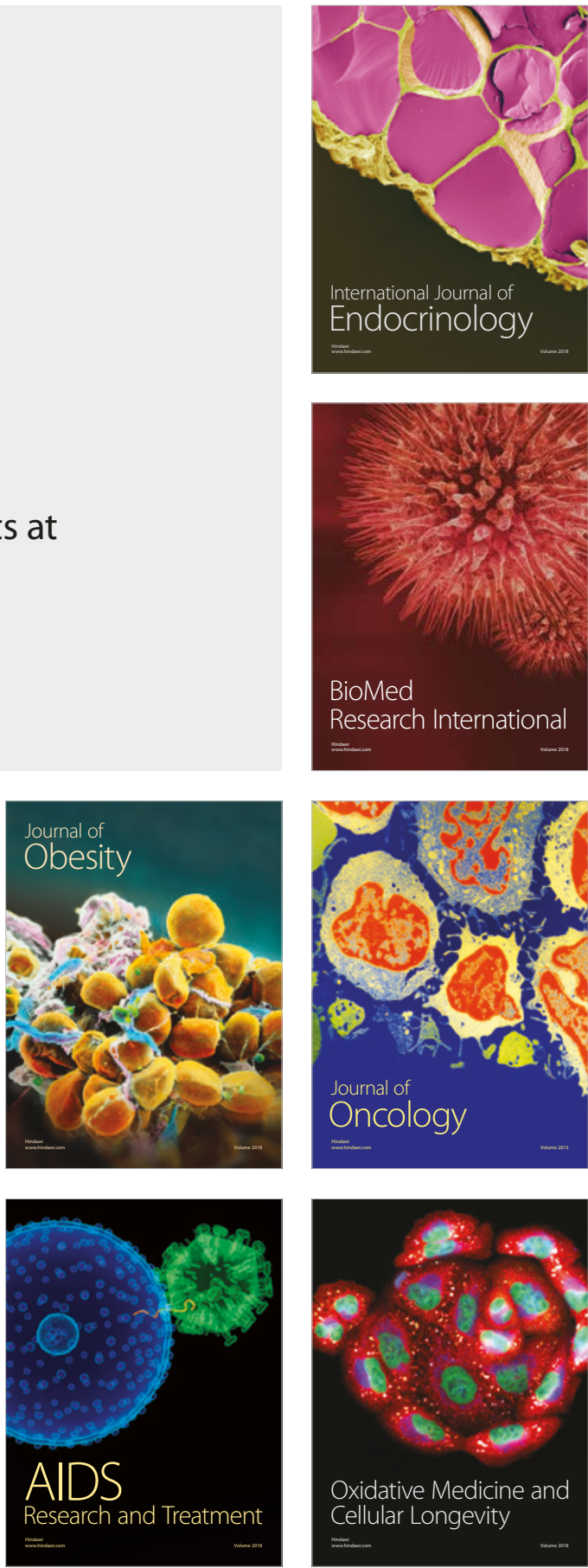